\title{
AKULTURASI SAINS, TEKNOLOGI DAN BUDAYA UNTUK PENINGKATAN KUALITAS PENDIDIKAN BERBASIS KEARIFAN LOKAL
}

\author{
Suranto \\ Guru Besar Jurusan Biologi, Fakultas MIPA Universitas Sebelas Maret
}

\begin{abstract}
The values of local knowledge is the basis of great value for nature conservation, development of local products and development of national character. Indigenous development efforts need to be made by all parties and the whole society, so that the direction of development based on their own national identity. This can be exemplified in the national figures are recognized worldwide, while sticking to the philosophy of the nation. Positive impact on improving the quality of education is expected to be achieved as a result of acculturation between science, technology and culture. Pancasila should be a solid foundation for the development of science and technology, so that Indonesia become a nation of character
\end{abstract}

Keyword: acculturation, science, technology, culture

\section{PENDAHULUAN}

Kemajuan suatu negara sangat tergantung dari kemajuan Sains dan Teknologinya. Asumsi yang salah banyak mewarnai bangsa yang negaranya belum maju, dimana untuk memajukan sains dan teknologi masalah kearifan lokal yang bersumber pada budayanya tidak perlu menjadi pertimbangan. Asumsi atau pendapat tersebut tidak benar. Negara maju di Asia seperti Jepang telah membuktikan bahwa Sain dan teknologi yang sekarang telah berkembang pesat, ternyata tidak melupakan akan budaya mereka. Pakaian Kimono, adalah salah satu bukti nyata. Di jaman yang begitu modern mereka tidak melupakan akan kebanggaan berbusana Kimono. Budaya disiplin dan kerja keras juga merupakan bagaian hidup yang mereka aplikasikan setiap hari. Budaya malu, yang ditunjukkan oleh guru dan pemimpinnya. Budaya yang mereka tunjukkan dapat menjadi teladan rakyatnya.

Kearifan lokal yang lain seperti yang terjadi di negara seperti India untuk memanfaatkan Sungai Gangga sebagai tempat yang dikeramatkan telah menjadikan sungai tersebut tidak diperlakukan semaunya, seperti layaknya sungai-sungai di Indonesia sebagai tempat pembuangan sampah. Nilai kearifan lokal yang mereka punya tetap dijaga eksistensinya, sehingga secara ekologis dan humaniora dapat dirasakan manfaatnya. Negara maju juga menunjukan perilaku akan aplikasi kearifan lokal dinegaranya. Kota-kota besar di dunia, menjadikan sungai sebagai kebanggaanya, sehingga muncul apa yang disebut "water front city". Sebuah konsep pengembangan kota modern yang berbasis pada sungai sebagai pintu masuknya, dengan segenap pernak pernik budaya lokalnya, yang dikemas menjadi satu paket acara untuk tamu negara atau wisata domestik dan mancanegara. Jaman yang serba maju dan luar biasa sekarang ini, banyak orang yang mendambakan bagaimana budaya lokal dengan segala keunikan lokalnya telah menjadi incaran untuk dapat dikaji sebagai obyek wisata. Pertumbuhan penduduk dunia khususnya di Negara maju seperti Jerman, Jepang dan Italia menunjukkan angka yang sangat rendah, bahkan ada yang minus. Negara-negara yang sedang berkembang, tingkat pertumbuhan penduduknya relatif tinggi, bahkan diperkirakan pertambahannya mencapai lebih setengah milyard manusia di China pada tahun 2030 (Suranto, 1999). Negara seperti Pakistan dan India menyumbangkan jumlah penduduk yang cukup tinggi pula. Indonesia juga diproyeksikan akan mempunyai jumlah penduduk sekitar 307 
Juta. Gambaran tersebut tentunya akan menjadi perhatian yang cukup serius bagi kita semua, manakala mayoritas penduduk tersebut mengkonsumsi jenis pangan padipadian.

Tahun 1950-an hampir semua Negara di dunia baik kala itu berstatus sebagai Negara masih belum maju dan maju hampir boleh dikatakan tidak mempunyai masalah tentang pangan mereka. Bahkan Indonesia pada tahun 1984-an. Negara kita swasembada pangan. Demikian juga pada tahun 1990-an ada beberapa Negara mengalami kekurangan pangan walaupun nampaknya kekurangan pangan tersebut terkonsentrasi di Negara-negara Asia (Misal; India, China, Banglades) dan Negara-negara Afrika (Suranto,1999). Kelanjutan akan divisit pangan dunia tersebut, nampaknya akan tetap berlanjut pada tahun 2030, sehingga antisipasi tentang hal itu harus sedini mungkin diantisipasi secara positif. Hal ini tidak boleh hanya menyangkut Departemen pertanian yang harus bertanggungjawab. Usaha peningkatan produksi padi-padian tidak akan berarti apa-apa manakala laju pertumbuhan penduduk tidak dapat dikendalikan (diatur) dengan baik. Ini berarti jumlah penduduk harus tumbuh, tetapi dalam presentase (\%) yang tidak mengawatirkan. Usaha-usaha nyata untuk meningkatkan kualitas manusia Indonesia dari sisi pendidikan dan kesehatan juga harus dilakukan secara bersama-sama dengan sektor atau bidang-bidang yang lain.

\section{PEMBAHASAN}

\section{Sumber Daya Manusia yang Berkarakter}

Manusia adalah insan yang berpengetahuan dan berbudaya. Inilah bukti bahwa manusia tidak sama dengan makhluk lain. Oleh karenanya mereka mampu menciptakan karya besar di muka bumi ini, dan sekaligus bermanfaat untuk kesejahteraan umat manusia. Sumber daya manusia Indonesia termasuk didalamnya mahasiswa agar dapat menjadi calon insan cendikia yang berkarakter, paling tidak mempunyai sifat yang sebaiknya dapat bertumpu pada 1)Panutan tokoh nasional, 2)menjujung tinggi budaya akademik dan budaya nasional dan 3) harus percaya pada kemampuan bangsanya sendiri. Ketiga hal tersebut akan memberi warna yang kuat bagaimana manusia Indonesia termasuk didalamnya mahasiswa dalam perjalanannya dapat menjadi calon insan cendekia yang berkarakter.

\section{Panutan tokoh nasional}

Sebagai insan yang dapat melihat akan keluhuran budi pekerti para tokoh pendiri bangsa baik sebelum, semasa dan sesudah kemerdekaan. Kita dapat mencerna dengan seksama dan merenungkan akan Keluhuran budi perkerti serta kehebatan Bapak Pendidikan Indonesia - Ki Hajar Dewantara yang mengajarkan kepada kita agar dapat; Ing ngarsa sung tuladha ing madya mangun karsa tutwuri handayani. Ajaran ini sungguh tiada duanya di dunia, mengandung makna filosofis yang begitu tinggi untuk dapat diterapkan, tidak saja di bidang pendidikan tetapi juga hampir di seluruh sendi kehidupan berbangsa dan bernegara. Sebagai bagian dari masarakat Indonesia, manakala kita mendapat kepercayaan memimpin akan lebih baik kiranya apabila dapat memberi contoh keteladanan kepada anak buahnya, hal ini berarti ing ngarsa sung tuladha. Kemudian ditengah- sebagai pemimpin kita diharapkan dapat membangkitkan atau memotivasi anak buahnya untuk berkarya (ing madya mangun karsa) dan selanjutnya kita harus mampu dari belakang mengikuti dan menyemangati dan mendorong dengan sepenuh hati agar anak buahnya terus bergerak maju. Ajaran ini luar biasa apabila dapat dilakukan setiap pemimpin bangsa termasuk didalamnya kita yang bergerak dibidang pendidikan.Kita ikut berbahagia bahwa bidang kebudayaan telah kembali disatukan dalam rumah besarnya Kementriann Pendidikan dan Kebudayaan. Hal ini akan mengintegrasikan urusanurusan kebudayaan nusantara kita dalam aktifitas pendidikan Indonesia dalam rangka membentuk insan cendikia muda yang berkepribadiaan Indonesia. 
Selain tokoh pendidikan kita tersebut, dimana hari kelahirannya menjadi hari pendidikan nasional Indonesia, kita juga punya tokoh panutan yang lain yaitu Bung Karna dan Bung Hatta sebagai putra terbaik bangsa Indonesia. Kedua tokoh kita ini sangat tepat kiranya untuk dijadikan teladan yang berkarakter sangat kuat untuk bangsa dan Negara, karena di dalam mengarungi kehidupan berbangsa dan bernegara mereka selalu memberikan contoh yang nyata. Sejarah telah mencatat bagaimana konsistensi kedua Sang Dwi Tunggal ini menunjukkan pendiriannya untuk mencapai cita-citanya mendirikan negara merdeka-Indonesia. Hukuman dan jenis-jenis pengasingan dan pengembosan semangat patriotisme yang telah dilakukan penjajah tidak menyurutkan tekad mereka untuk membentuk negara kesatuan republik Indonesia (NKRI). Negara yang diidamidamkan tersebut juga dibangun atas dasar budaya bangsanya sendiri yang terkristalkan dalam bentuk falsafah Pancasila.

Negara yang diproklamirkannya pada tanggal 17 Agustus 1945 berdasarkan Pancasila adalah satu-satunya negara di dunia yang mempunyai dasar negara yang unik sekaligus membanggakan kita semua. Dasar negaranya bukan berasal dari pemberian penjajah yang pernah menindasnya, menggunakan dasar negara yang berasal dari salah satu faham dunia yang telah teruji eksistensinya. Secara tidak sadar bahwa Pancasila sebagai dasar negara yang telah teruji mampu mempersatukan kita seluruh masyarakat Indonesia yang beragam suku, bahasa dan budaya ternyata juga diakui dunia. Presiden USA adalah bukti nyata bagaimana dia mengakui sekaligus membanggakan akan hadirnya dasar negara Pancasila.

Australia juga mengakui akan eksistensi Pancasila sebagai pemersatu bangsa Indonesia yang mereka kenal sebagai the five principles of Pancasila. Mereka mempercayai bahwa dasar negara Pancasila itulah yang menjadikan kita seluruh warga bangsa Indonesia masih utuh dalam bingkai NKRI. Inikah kiranya kita sebagai bangsa Indonesia yang akhir-akhir ini mulai terjadi gesekan/perpecahan atau konflik antar etnis atau masalah ras maupun agama,karena kita telah melupakan akan arti penting hadirnya dasar negara Pancasila di setiap sendi kehidupan berbangsa dan bernegara serta bermasyarakat.

\section{Budaya Akademik dan Budaya Nasional Indonesia}

Budaya Akademik

Sebagai bagian tak terpisahkan dari civitas akademika, mahasiswadan dosen harus menjunjung tinggi budaya akademik dan budaya bangsanya. Budaya akademik sebagai ciri khas masyarakat ilmiah di kampus pendidikan tinggi, yang ditandai dengan kebenaran ilmiah yang harus tetap dijunjung tinggi walaupun berat untuk dilaksanakannya. Menjunjung tinggi budaya akademik pada akhir-akhir ini semakin terasa sangat penting untuk dijaga dan dilaksanakan, oleh karena terjadinya plagiasi yang mendera tidak saja para mahasiswa tetapi juga para pengajarnya. Sifat kejujuran yang harus dipunyai setiap insan yang termasuk masyarakat ilmiah adalah suatu keharusan. Kita boleh dengan sangat leluasa mensitir ataupun menggunakan pendapat orang lain dalam tulisan kita, namun yang tidak boleh lupa kita harus lakukan adalah mengapresiasi mereka dalam teks-tulisan kita. Di samping budaya tersebut kebiasaan akan menghormati penemuan yang lebih tua, juga suatu hal yang berakar pada budaya akademik. Penemuan ilmiah yang awal mulanya menggunakan alat-alat optik sederhana juga tetap harus dihargai sebagai budaya penghargaan ilmiah. Tanpa penemuan awal tersebut para ilmuwan akan menemui kesulitan dalam melacak untuk penelitian berikutnya, terkecuali penemuan yang sifatnya baru.

\section{Budaya nusantara}

Selain budaya akademik, budaya Indonesia yang sejak dulu telah dirintis dan dibangun oleh para pendiri dan tokoh-tokoh 
republik ini juga harus terus dipupuk dan diejawantahkan dalam kehidapan seharihari bagi mahasiswa Indonesia. Gotongroyang adalah budaya nasional Indonesia. Budaya ini tidak saja mengajarkan kepada kita untuk saling bekerjasama,bahu membahu mengatasi kesulitan dan kekurangan orang lain tetapi juga terjadinya penanaman respek pada orang lain dan empathi yang perlu tetap ditumbuhkembangkan dalam masyarakat Indonesia yang semakin modern dan global. Kontek ini mahasiswa adalah bagian dari masyarakat Indonesia yang belatarbelakang pendidikan tinggi, seyogyanya juga menjadi teladan di masyarakat walaupun sekecilapapun perannya.

Menghargai dan menjunjung tinggi akan budaya nasional Indonesia bukan berarti menampik adanya budaya luar yang positif dalam membangun karakter mahasiswa kita. Kita melihat bahwa ada sebagian kecil di lingkungan kita ada yang mendapatkan pendidikannya dari luar negeri. Ini berarti mereka juga kadangkadang membawa budaya yang pernah mereka jalani selama belajar di negara tersebut. Dalam kontek ini maka penularan budaya akademik yang baik seperti budaya tepat waktu konsisten pada pendapat yang benar atau budaya senang membaca serta menghargai pendapat orang lain adalah halhal yang sangat pantas untuk diadopsi atau ditiru.

Selain itu budaya yang baik dalam bersosialisasi dengan anggota keluarga lainnya, nampaknya juga patut untuk dipertimbangkan. Walaupun pelaksanaanya memerlukan waktu yang mungkin cukup lama. Kebiasaan akan membuat hati orang terluka di tempat umum mungkin tidak terasa kita lakukan. Namun karena hal itu sudah biasa maka hal tersebut dianggap tidak menjadi menjadi masalah. Namun seiring dengan perkembangan peradaban manusia, lama-kelamaan hal tersebut dapat mengganggu hubungan mereka karena dapat dipandang sebagai melukai hatinya. Hal seperti itulah yang biasanya tidak terjadi atau jarang sekali terjadi di negara maju manca negara. Bangsa yang mempunyai budaya luhur yang tunggi, hampir pasti mereka biasanya dapat menghormati dan bertindak bijakasana terhadap alam. Karena etika lingkungan mengajarkan kepada kita bagaimana manusia bertindak atau manusia berperilaku terhadap lingkungan hidup di sekitarnya (Kerap, 2002). Di dalam menyikapi alam ini salah satu prinsip etika lingkungan kita harus bersifat arif dan bijaksana. Sifat tersebut mendorong manusia untuk dapat menjaga bagaimana budaya lokal yang telah berkembang sejak dahulu kala, dapat dikaji secara ilmiah demi kebaikan lingkungan, dan akhirnya akan dampak positif dalam kehidupan manusia. Banyak contoh yang dapat kita petik, bahwa bencana alam yang sering mengancam manusia, baik itu banjir bandang dan kekeringan yang menimpa sebagian warga bangsa, sebenarnya bersumber pada perbuatan yang pernah mereka lakukan baik itu yang disengaja atau tidak disengaja, dilakukan secara individu maupun kelompok, baik secara sadar atau tekanan pihak lain maupun karena pengaruh aktor dari dalam negri atau luar negeri.

Nilai-nilai kearifan lokal hendaknya menjadi modal dasar yang berharga tidak saj dalam pelestarian alam, dimana manusia hidup didalamnya, namun sebenarnya juga dapat membantu juga dalam dunia kesehatan-seperti produk-produk lokal jamu yang dapat berprestasi ditingkat dunia, seperti Sido Muncul. Dunia sedang mengincar akan kekayaan Sumber daya alam bangsa-bangsa yang relatif belum begitu maju teknologinya. kekayaan SDA dengan kekayaan kearifan lokalnya secara pelan dan seksama, mereka akan,telah dan sedang mengeksplorasi untuk kepentingan bisnisnya. Kita wajib waspada terhadap hal itu, dan berusa untuk tidak terlena atas bujukrayuaannya. Karena kalau tiadak hatihati SDA dengan kearifan lokalnya kita terkikis dan bahkan hilang akibat kemajuan teknologi. Padahal kearifan lokal kita dapat berkontribusi dalam peningkatan kualitas pendidakan kita termasuk dalam 
membentuk insan-cendikia Indonesia yang berkarakter.

\section{Percaya kepada kemampuan bangsa sendiri}

Sebagai bangsa yang besar, mahasiswa termasuk kelompok elit kecil karena kualitas pendidikannya. Sejarah membuktikan bahwa bangsa Indonesia mempunyai tokoh yang berkaliber Internasional baik dalam bidang politik, ekonomi-lingkungan, kependudukan ataupun IPTEK. Dari rekam jejak yang pernah kita lihat, bangsa Indonesia mampu menciptakan pesawat terbang dengan tokoh sentralnya BJ Habibi. Kemampuan kita tentunya tidak saja diakui oleh bangsa Indonesia saja tetapi juga dunia internasional. Hal ini terbukti dengan dijalinnya kerjasama perusahaan pesawat besar dunia dengan PT DI kita.

Di samping itu kemampuan putra-putra terbaik Indonesia yang bergerak di ALUTSISTA juga lumayan cukup maju seperti yang dihasilkan PT PINDAD dan PAL Indonesia. Hal ini ditandai dengan adanya beberapa negara yang pesan atas produk kita. Hal ini membuktikan, bahwa sebenarnya bangsa Indonesia adalah bangsa yang mempunyai kemampuan IPTEK yang canggih, namun agaknya terkendala dengan modal beaya. Tentunya hal,ini tidak akan terjadi manakala politik ketatanegaraan kita berpihak pada produk nusantara yang dihasilkan dari putra-putri terbaik Indonesia dari pada produk mancanegara.

Bukti lain bangsa Indonesia pernah jaya dan mampu mengatasi kecukupan pangan sendiri, juga diakuai dunia. Demikian juga program keluarga berencana yang pernah menjadi kesuksesan bangsa kita yang dalam kenyataannya juga diadopsi bangsa lain seperti Cina.Tidak kalah pentingnya bahwa bangsa Indonesia juga diakui dunia dalam dunia politik. Beberapa gelintir tokoh kita yang berkiprah ditingkat dunia seperti diplomat Adam Malik, Ali Alatas dan Mochtar Kusamaatmadja adalah contoh kecil putraputra terbaik Indonesia yang dalam kemampuan kariernya juga diakaui dunia. Selain itu kita juga mempunyai tokoh lingkungan seperti Emil Salim, dimana eksistensinya juga diakui dunia. Berangkat dari kenyataan tersebut tidak berlebihan kiranya apabila bangsa Indonesia seharusnya percaya kepada kemampuan bangsanya sendiri untuk tetap maju dan berjaya tanpa harus meninggalkan budayanya

\section{Pendekatan Bioteknologi Molekuler untuk Ketahanan Pangan versus Kearifan lokal} Kemajuan sain dan teknologi termasuk didalam bagaimana mengkonstruksi tanaman pangan dengan bioteknologi moden/molekuler, sebaiknya dapat memadukan nilai-nilai budaya lokal sehingga didapat sinergitas yang sebesarbesarnya, tanpa harus mengorbankan budaya-budaya lokal di daerah dimana aktifitas tersebut berlangsung. Dengan demikian maka perkembangan sain dan teknologi khususnya dalam aplikasinya untuk menciptakan pangan transgenik, dapat berlangsung dengan baik, dan berdampak positif pada kualitas pendidikan-karena mengkonsumsi makanan yang bergizi tinggi,tanpa mengurangi esensi nilai budaya yang dimilikinya.

Timbulnya banyak penyakit pada tanaman dan buah-buahan dapat menyebabkan penurunan kualitas hasil panen atau bahkan dapat gagal panen. Hal ini dapat terjadi manakala serangan virus pada individu tanaman dan bahkan manusia masih dalam usia sangat muda terjadi, maka kemungkinan serangan penyakit tersebut terhadap individu hingga mati adalah sangat tinggi.

Upaya untuk mengantisipasi hal tersebut maka usaha secara klasik untuk melakukan penyilangan-penyilangan dalam rangka mendapatkan bibit unggul tanaman padi-padian perlu terus ditingkatkan. Seiring dengan itu rekayasa genetika untuk menciptakan tanaman transgenic yang mempunyai sifat-sifat unggul seperti tahan terhadap serangan virus atau untuk mendapatkan padi-padian yang 
mengandung gizi tertentu yang lebih tinggi konsentrasinya nampaknya perlu terus dikembangkan (Suranto, 2004, dan Suranto, 2006). Rekayasa genetika dengan memanfaatkan gen tertentu (Misal, gen CP) pada virus yang menyerang pada tanaman, telah membuktikan keandalanya dalam memproteksi tanaman tersebut dari serangan virus yang bersangkutan (Brown and Kane (1994); Suranto (2004) Dalam kasus ini dengan dimasukkannya gen $\mathrm{CP}$ dari virus Johnsongrass Mosaic (JGMV) pada tanaman jagung, maka tanaman jagung tersebut telah menunjukkan kekebalanya dari serangan virus JGMV (Suranto,1999).

Penguasaan transformasi genetic untuk ketela pohon, maka memungkinkan untuk menciptakan tanaman pangan dari varietas ini yang jumlahnya banyak sekali, untuk menghasikan tanaman kebal terhadap serangan Cassava Mosaic Virus ( Li et al., 1996). Selanjutnya upaya manusia untuk mengembang-biakan secara besar-besaran dengan kualiatas dan kuantitas yang bagus adalah suatu yang mendesak untuk dilakukan, dalam rangka pemenuhan dan penyelamatan tersedianya makanan di Negara-negara Afrika. Di samping jenis makanan tersebut, upaya manusia untuk menciptakan kualiatas padi yang mengandung jenis kandungan gizi tertentu terus usahakan, seperti Golden rice yang mengandung banyak beta carotene. Uji laboratorium terhadap beras ini terus dilakukan sampai hasil yang diharapakan dapat dicapai, sebelum padi ini benar-benar dilepas untuk para petani.

Penemuan-penemuan sejenis untuk menciptakan tanaman transgenic dengan memanfaatkan gen tertentu dari beberapa organisme yang menyerang tanaman, menunjukkan keberhasilannya (Conner, 1997) dan ini telah mampu membantu mengatasi masalah penyakit tanaman dan membuka cakrawala baru dalam menghasilkan tanaman yang unggul yang bebas dari penyakit. Dan dihasikannya produk pangan yang mengandung gizi tertentu yang lebih baik (James, 1998).
Dengan demikian hal ini tentunya, akan berdampak positif pada kehidupan bangsa dan akhirnya akan bermanfaat dalam ikut serta menciptakan ketahanan pangan dunia. Beberapa contoh produk transgenik yang telah beredar di pasaran dan terus dikembangkan untuk tujuan pemenuhan kebutuhan pangan dunia, seperti yang dicatat oleh James (2009). Produk transgenik ini telah banyak bermanfaat tidak hanya bagi warga bangsa dimana produk trangenik tersebut telah ditanam pada skala yang cukup luas tidak hanya di negara maju tetapi juga telah banyak tersebar di negara-negara berkembang terutama di benua Asia dan Afrika.

\section{PENUTUP}

Perkembangan sain dan teknologi hubunganya dengan kearifan lokal dari budaya yang dimiliki bangsa Indonesia, maka tidak berkelebihan kirannya apabila arah pengembangannya bertumpu pada jati diri bangsa sendiri. Ini dapat diteladani dari tokoh-tokoh nasional yang diakui dunia,dengan tetap berpegang teguh pada falsafah bangsa. Dampak positif untuk peningkatan kualitas pendidikan diharapkan dapat tercapai sebagai hasil akulturasi yang baik antara sain, teknologi dan budaya.

\section{DAFTAR PUSTAKA}

Brown, L.R and H.Kane. 1994. Reassessing the Earth's Population Carrying Capacity. S.Linda (ed), The Worldwatch Environmental Alert Series.London: W.W.Northon \& Company.

Conner, A.J. 1997.Genetically Engineered Crops. RSNZ, Wellington.

James C. 2009. Global Status of Commercialized Biotech/GM. Crops ISAAA Briefs 41

James, J. 1998. Global Review of Commercialized Transgenic. ISAAA.pp: 1-43

Li, H.Q., Sauter C., Potrykus I. and PuontiKaerlas J. 1996. Genetic 
Transformation of Cassava (Manihot esculenta C). Nat.Biotech. 14:736740.

Kerap S. 2002. Etika Lingkungan. Jakarta: Penerbit Buku Kompas. PT Kompas Media Nusantara

Suranto. 1999. Krisis Pangan Dunia dan Prospek Pendekatan Molekul untuk Mengatasinya. Hayati; Jurnal Nasional Terakreditasi. IPB, Vol.6.No.2.pp:47-50

Suranto. 2004. Peran Bioteknologi Molekuler dalam Menghadapi Era Global di Bidang Riset dan Teknologi. Pidato Dies Natalis UNS ke XXVIII. Solo;11 Maret 2004

Suranto. 2004. Peran Bioteknologi Molekuler dalam Menanggulangi Masalah Pangan dan Kesehatan
.Seminar Nasional dan Lokakarya Bioteknologi Molekuler. Solo, 16 Maret 2004

Suranto. 2004. Bioteknologi Virus Tanaman untuk Kecukupan Sandang dan Pangan. Keynote Speaker pada Seminar Nasional Hari Padi Internasional-Sosialisasi dan Promosi Hasil Penelitian Pertanian MarosSulawesi Selatan, 23 Agustus 2004

Suranto. 2006. Bioteknologi Virus tumbuhan-Tungro dan Perannya dalam Ketahanan Pangan Indonesia. Seminar Nasional:Status Program Penelitian Tungro untuk Mendukung Keberlanjutan Padi Nasional. Departemen Pertanian; MakasarSulawesi Selatan, 7-8 September 2006 